\title{
Procedural Skills, SketchUp and Vodcasting: Distance Teaching of Design Drawing Skills and Student Learning Autonomy
}

\author{
David Ellis', William E. Boyd ${ }^{2}$ \\ ${ }^{1}$ School of Education, Southern Cross University, Coffs Harbour, Australia \\ ${ }^{2}$ School of Environment, Science \& Engineering, Southern Cross University, Lismore, Australia \\ Email: david.ellis@scu.edu.au
}

Received 26 April 2014; revised 20 May 2014; accepted 10 June 2014

Copyright (C) 2014 by authors and Scientific Research Publishing Inc.

This work is licensed under the Creative Commons Attribution International License (CC BY).

http://creativecommons.org/licenses/by/4.0/

(c) (i) Open Access

\begin{abstract}
The popularity of sites like YouTube demonstrates the potential preference for users to use video podcasts (vodcasts) as an instructional tool. As educators have been encouraged to become more literate in authoring Web 2.0 technologies, the implementation of vodcasts as an effective pedagogy has been increasingly used in educational settings. The recent proliferation of distance education courses caused educators in higher education settings to consider why some programs are more suitable for distance education than others, and whether procedural knowledge and skills that are required in various industries may be able to be delivered using contemporary technologies. This article discusses the efficacy of using vodcasting as a pedagogical tool, in developing procedural knowledge and skills in computer aided design and drawing, to pre-service teachers studying via distance education, and demonstrates the capacity for vodcasts to foster autonomous student learning.
\end{abstract}

Keywords

Vodcasts, Procedural Knowledge, Web 2.0, Distance Education

\section{Introduction}

The interactive nature of Web 2.0 has enabled users to generate content and use technology for a variety of purposes such as entertainment, self-promotion and self-education. Importantly, the adoption and adaptation of Web 2.0 technology in education is increasingly being used to provide valid and credible pedagogical options in the world of the $21^{\text {st }}$ century university. This is a world that is increasingly characterised by institutions, faculty 
and students being networked, global and technological (Boyd \& Horta, 2011; Boyd \& Ellis, 2013; den Exter et al., 2012). Both the evolving external context of education and the opportunities provided by Web 2.0 technology require educators to re-think the use of teaching and learning methods and approaches. In demonstrating, for example, a relatively simple way of using a typical example of collaborative, open-source Web 2.0 technology, Google SketchUp 3D Warehouse, in an eco-technology design course, Boyd \& Ellis (2013) identified a role for Web 2.0 technology to assist teachers who may not have a strong Web 2.0 technology background or, indeed, a strong eco-design background. On the other hand, in identifying challenges of such technology to conventional thinking about the primacy of individual authorship (for example), they now understand that the "primary issues around the individual of such Web 2.0 technology in teaching are less technical than social” (p. 412). While they identified social issues concerning ownership and authorship of knowledge-and the potential that these intersect, possibly negatively, with established academic governance process, especially in terms of integrity-they support a call by other authors (e.g. van Aalst, 2009; Cress \& Kimmerle, 2008; Thompson \& Absalom, 2011; Boyd \& Newton, 2011) for the development of "appropriate social systems, dynamics and cultures, that allow for the acknowledgment and validity of shared knowledge and, thus, shared output generation as valid, honest and unproblematic" (p. 412).

Of course, such an engagement is complex. In a literature review on the adoption and use of Web 2.0 technology in education, den Exter et al. (2013) identified six important social relationships between Web 2.0 technology and learners: engagement (helping students engage with learning); social interaction: (supporting social interaction in the learning process); conceptual understanding (enabling students to work at conceptual level of understanding); critical thinking: (enabling students to develop critical thinking); construction of collaborative knowledge (enabling students to collaboratively build knowledge); and construction of individual knowledge (enabling students to build their own knowledge). In reviewing problems and challenges for students using Web 2.0 tools, they also identified six important matters. These, importantly, appear to apply to both teachers and learners, thus reinforcing the importance of social relationships in the learning environment. These are: content (editing \& deleting, peer commenting); process (accountability for student participation; student role versus teacher role); guidance (inexperience, poor past experience, fear); teacher presence (need and role for teacher participation); solitary learners (student unprepared for shared authoring and group work); and design and pedagogy (scaffolding, pedagogic potential to match tool design, task authenticity). den Exter et al. (2013) draw this complex together in their figure 3, a conceptual model of a "Web 2.0 community of inquiry, illustrating relationships between teacher, student and the integrated use of Web 2.0 tools” (p. 3). This model comprises multiple relationships, and focuses around three nodes: "Student”; "Integrated use of Web 2.0 tools"; and “Teacher”. Importantly, the two primary nodes are "Student" and "Integrated use of Web 2.0 tools".

With the centrality of the student in mind, it is important to consider the student reception of educational Web 2.0 technology. The escalation of digital technology tools has enabled the quick capture, uploading and editing of input items such as screen-captured images, cameras, audio and video. To facilitate this process easily, Web 2.0 has provided this shared infrastructure, located in websites such as YouTube, Facebook and Twitter, enabling users to generate and share content easily. On the face of it, therefore, such systems and infrastructures provide the environment to support a strong inceptive for contemporary students to enhance their learning with ease. However, as users are motivated to use this technology for both extrinsic and intrinsic reasons (Shin, 2009; Shin \& Kim, 2008), their enthusiasm begs questions of whether we can use this familiar tool to develop their knowledge and skills in specific areas. This article draws on a relatively simple adoption of a Web 2.0 tool-interactive videos (vodcasts) — using the example of teaching technical design and drawing skills. It examines whether such a method or pedagogy can provide the support that distance education students may need or perceive to need in undertaking a complex drawing task and, as a result, develop the essential procedural skills and knowledge required to complete the task satisfactorily.

The terminology used in this article_-vodcast_-stems from a common misuse of the term podcast for recorded videos called podcasts. Meant for digital media sound files, the term podcast is the combination of the iPod portable media device and the term broadcasting (Hammersley, 2004). Incorporating sound and video files, as technology advances, has created a new form, whose correct name should be the "vodcast”. However, given the nature of the literature around the use of the term, this article uses the terms video podcasting and vodcasting.

\section{Educational Context}

Declarative knowledge, the knowledge that "something is the case” (Oosterhof, 2012: p. 5) is said to be know- 
ledge about a particular subject or domain that increases over time through both the accumulation of knowledge and the interconnected network of experiences (Chi \& Ohlsson, 2005). In the context of developing declarative knowledge in higher education settings, the pedagogy behind the preparation of pre-service schoolteachers can be found packaged into specific units and applied explicitly through student engagement in lectures, tutorials, readings, experiences and, tacitly by undertaking assignments and examinations. The application or transfer of this knowledge around a particular unit, subject or domain into an informed and recognised process can be described as "procedural knowledge". It is the embodiment of domain knowledge through procedures in knowing "how to" perform a task, lending to the idea of procedural knowledge following declarative knowledge (Anderson \& Fincham, 1994). A traditional face-to-face pedagogy in higher education can develop procedural knowledge through demonstrations, tutorial exercises or even video sessions. However, for the distance learner, access to this information may be impeded.

One simple solution may be for higher education programs and educators to focus on the development of declarative knowledge by limiting opportunities for studying via a distance, though this does not have to be the case. Educators in distance education programs have modified their pedagogical practice to suit the availability of the technology available at the time. As technology has evolved, so have the tools that educators have adopted, "mail, telephone, radio, television, tape recording, computer" (Feisel \& Rosa, 2005: p. 125). The relatively recent combination of two technological innovations, the computer and the internet, has created an opportunity for educators to rethink their pedagogical practices when dealing with distance education students. Simply having access to the technology does not ensure quality educational outcomes, or industry acceptance; as Bourne et al. (2005) point out, for online engineering education to be accepted, online education providers need to ensure that "the quality of online courses must be comparable to or better than traditional classroom" (p. 1).

Due to the advent of Web 2.0 technologies and the adoption of Web 2.0 into higher education settings, educators can now begin to deliver programs that may have previously been considered unsuitable (Bourne et al., 2005: p. 135) due to their practical nature, as they require the development of essential procedural skills and knowledge expected by the relevant vocational industry. As a result, disciplines such as dentistry have been delivered via a distance. The thoughts of having root canal from a dentist who studied via distance education may make some patients feel uneasy. However, postgraduate programs such as the one being offered at King's College, London, combine Web 2.0 pedagogies and intensive residential programs to develop procedural knowledge and skills in what is called "flexible delivery".

A field of education that exemplifies the pedagogy of experience, or experiential learning (Falchikov \& Boud, 1989; Boud, 1993; Henry, 1989; Kolb, 1984; Healey \& Jenkins, 2000) in providing opportunities to demonstrate both declarative and procedural knowledge is Technology Education. Technology Education incorporates problem-based learning, where students learn by doing (Dewey, 1938), applying (and testing) their knowledge of materials through practical processes or experiences. This pedagogical approach, supported through Carroll's (1963) “Model of School Learning” and Bloom's (1968) work on "Mastery of Learning Strategies”, has evolved from the traditional, tried and tested master and the apprentice model in developing practical skills where students can master skills by the practising of "doing” (Hymel, 1988).

Technology Education, globally, is an education discipline that focuses on the development of theoretical knowledge (declarative knowledge) and its application through experiential, problem-based learning opportunities. Desired educational outcomes include the development of both explicit and tacit knowledge of what may be considered "best practice" in design and the manipulation of materials for production purposes. Its purpose, as argued by Putnam (1992: p. 3), is to provide understanding of the industrial world in an effort to satisfy vocational objectives. Students may engage in various technology strands, where they tend to be organised in schools under "occupational families" (Putnam, 1992: p. 5). More contemporary views consider Technology Education to be essential in the development of "Technological Literacy". That is preparing students with the knowledge and skills required to contribute in today's technology dominant society (Brown, R. A. \& Brown, J. W, 2010; Williams, 2009).

A common discussion around the adoption of external and flexible delivery of education has been along the lines of, "How can practical skills and procedural knowledge be taught in a flexibly delivered or external degree program?”. Various studies have demonstrated that there are several important characteristics regarding successful distance education (Bourne et al., 2005). It is important that the focus on online learning activities and use of tools found is most compatible with the model of pedagogy adopted, and that design and integration of Web 2.0 tools should be closely related to curriculum intent and pedagogical requirements. Important characteristics in- 
clude: asynchronous small group discussions; collaborative problem solving; reflective inquiry; competency-based outcomes; clear guidance on student activity and learning expectations; a facilitative teacher; and strong interactions between teachers and students and amongst students (Rudestam, 2004; den Exter, 2012).

To place this question in context, the Southern Cross University Bachelor of Technology teaching degree program moved to a flexibly delivered model in 2010, including the use of intensive practical workshops to develop student's procedural knowledge and skills. The reasons for this transition is not the intention of this article, although, as Parker (2003) comments in her work, higher education faculties are realising the "fiscal value of distance delivery" (p. 1); with the increasing amount of digital content available, combined with student enrolment concerns across the sector, this transition was not surprising or uncommon in the Australian higher education setting. To place externalisation of higher education courses into perspective, in 2010 the Australian Bureau of Statistics calculated that 1.2 million students were enrolled in a higher education degree across the country. Of that total, almost one million higher education students were enrolled as internal students (81\%), whilst 7\% of these students opted for a flexibly delivered program, having a mixture of both face-to-face and online education. This leaves the remaining $12 \%$ of students across the country choosing to study via a distance (ABS, 2010). The Bachelor of Technology Education program sits within this $7 \%$ of flexibly delivered programs within Australia.

Considering the practical nature of the Technology Education teaching specialisation, the expectations from both teacher accreditation authorities and potential employers from the various state and independent education sectors, require pre-service teachers who graduate with this education discipline possess both declarative and procedural knowledge and skills in their areas of technology specialisation gained through both theoretical studies as well as practical experiences (NSWIT, 2011: p. 8). Given the expectations of graduating teachers, the tension in an external education context resides around whether external delivery can develop these desired practical skills.

To counter these concerns, one could consider the application of effective Web 2.0 tools and pedagogies that, regardless of distance, demonstrate to students the sequential processes in the development of procedural knowledge. Contemplating one example, Schwan \& Riempp (2004) researched the effectiveness of using interactive videos for teaching the tying of various and complex nautical knots. They found that allowing students to engage with the interactive features of viewing an instructional video such as playing, stopping or reversing (to name a few), catered for individual cognitive processing differences, where students distributed their time and attention to particular parts of the video when required in a self-educative, student-centred process. In comparing this to students who did not have access to this interactive resource, their understanding and competence in learning developed faster.

Considering the results of various studies (Schwan \& Riempp, 2004; Bourne et al., 2005; Griffiths, 2010), the recording of content to develop declarative knowledge or the videoing of procedural processes can prove to be effective pedagogy in distance education. Readily available recording software such as Camtasia and its limited free version, Jing, can create a personalised instructional experience where the student only has to open a file to listen to the content or view a demonstration, complete with video and audio in a one-on-one asynchronous learning experience (Figure 1).

Building on the work of Kolb's (1984) experiential learning theory, various studies (Coggins, 1989; Dunn et al., 1989; Miller et al., 1987) suggest that not all students prefer to learn in the same way, and that past article-based distance education pedagogy did not cater for those students who may, according to Fleming's VAK model, be considered as visual or kinaesthetic learners (Fleming \& Mills, 1992; Fleming \& Baume, 2006). The work of Gee (1990) and Drago \& Wagner (2004) highlighted that, similar to in the classroom, distance education students have preferred learning styles, and that if these styles are catered for, positive academic achievement can be attained. Diaz \& Cartnal (1999), in considering the work of Gee, proposed an important idea: if distance education students are allowed to choose this method of education, they have more individualised preferences for learning, and prefer to engage with the learning material in their own time. This point indicates the need for educators to consider the ability to cater for students who wish to engage with the learning material asynchronously.

Due to the increased availability of Web 2.0 tools and the expectations in developing teachers' technological literacy (ITEA, 2005), there are opportunities for educators to achieve better educational outcomes through considered instructional design, and to offer a greater diversity of distance education courses, not just those that traditionally lent themselves to the traditional article-based pedagogy of readings and assignments (Gough, 1980). 


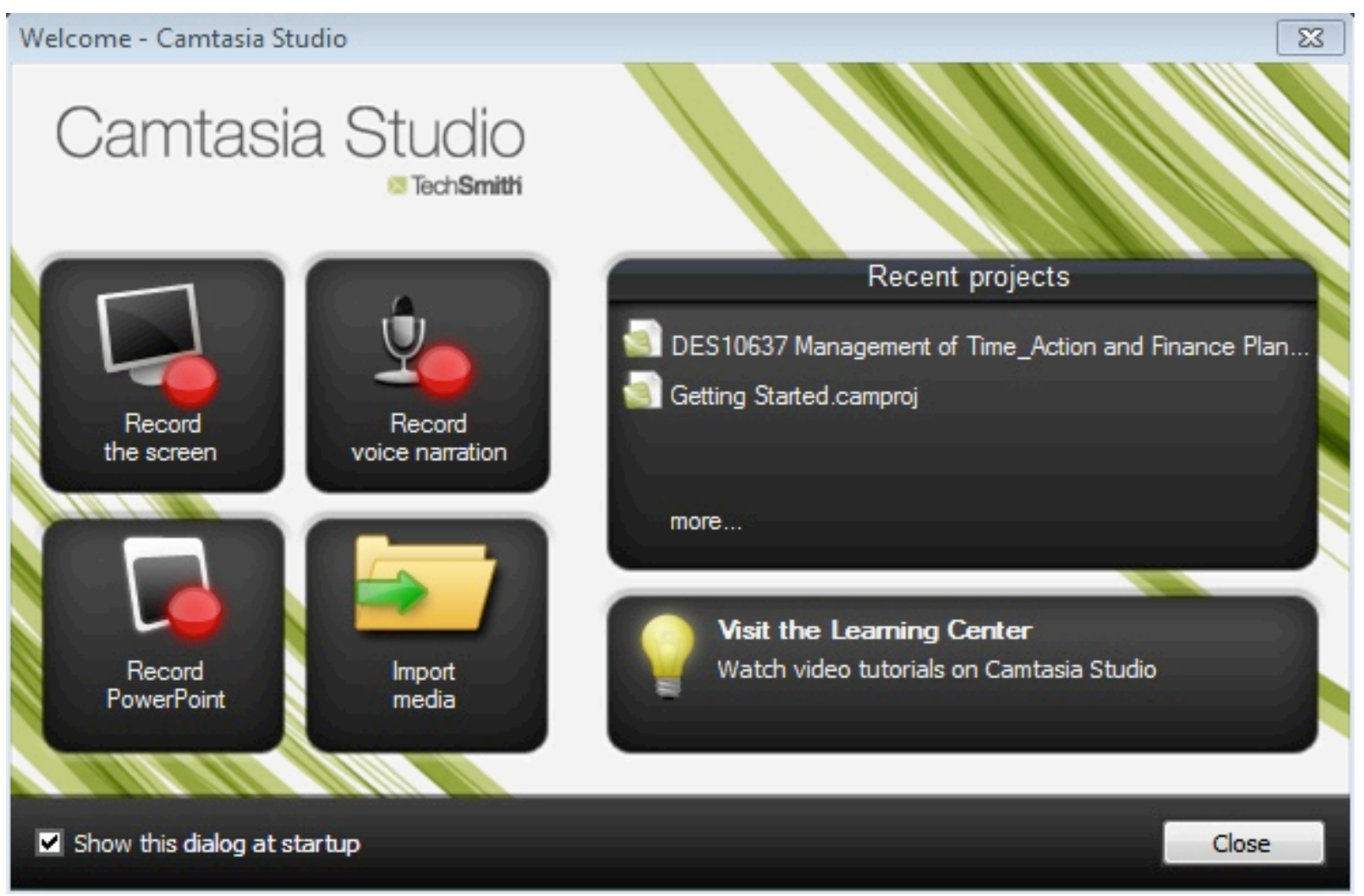

Figure 1. A screenshot of the recording software, "Camtasia”. Note the ability to record the screen for demonstrations, allowing for diversity to cater for students’ preferred learning styles.

This asks the question of whether the posting of videos for students' individual viewing is an appropriate instrument for fostering better engagement and deeper learning, compared to more traditional pedagogical approaches.

Clifton \& Mann (2011: p. 311) believe this is the case, as demonstrated in their study on the use of YouTube in nursing education. They state that today's students are "experienced in digital interaction from an increasingly early age", and they see resources such as YouTube as a method of engaging students, as it is a "recognised tool" (p. 312) providing information to a generation of learners. The internationally acclaimed writer in this area, Marc Prensky (2001), coined the term "digital natives", stating that these students can, and do, speak a "digital language". Prensky goes on to suggest that, as educators, "we need to reconsider both our methodology and our content" when teaching them (Prensky, 2001: p. 3). To engage with these students, we must become familiar with their culture, as they are not that enthusiastic to engage in our more traditional approach to pedagogy. It is a matter of bridging the digital native and the instructor - the "digital immigrant", i.e. those not born in the digital age, but who may be users of technology—divide (Prensky, 2001).

To simply provide the learning material for any student—whether face-to-face or distance education — does not encourage students to engage and draw on their comprehension of newly acquired knowledge. Akin to the concept of giving students a textbook and not providing any additional tuition, good pedagogy encourages students to engage with the material, to encourage deeper learning. Following the Revised Blooms Taxonomy, careful planning in the use of interactive video resources (such as YouTube) should complement the tried and tested characteristics of good pedagogy, providing opportunities for students to undertake the higher-order thinking tasks and deeper learning through the higher-order tasks of analysing, evaluating and creating (Anderson \& Krathwohl, 2001) (Figure 2). It is what we ask the students to do once they have accessed this material that matters.

\section{Method}

To test whether interactive videos could be used to develop procedural knowledge and skills over a distance, an 


\begin{tabular}{|c|c|c|c|c|c|}
\hline \multicolumn{6}{|c|}{ lower order thinking skills $\longrightarrow$ higher order thinking skills } \\
\hline remember & understand & apply & analyze & evaluate & create \\
\hline $\begin{array}{l}\text { recognizing } \\
\text { • identifying } \\
\text { recalling } \\
\text { • retrieving }\end{array}$ & $\begin{array}{l}\text { interpreting } \\
\text { • clarifying } \\
\text { : paraphrasing } \\
\text { : representing } \\
\text { - translating } \\
\text { exemplifying } \\
\text { • illustrating } \\
\text { - instantiating } \\
\text { classifying } \\
\text { - categorizing } \\
\text { - subsuming } \\
\text { summarizing } \\
\text { : abstracting } \\
\text { - generalizing } \\
\text { inferring } \\
\text { - concluding } \\
\text { - extrapolating } \\
\text { - interpolating } \\
\text { compadicting } \\
\text { - contrasting } \\
\text { - mapping } \\
\text { - matching } \\
\text { explaining } \\
\text { - constructing models }\end{array}$ & $\begin{array}{l}\text { executing } \\
\text { - carrying out } \\
\text { implementing } \\
\text { - using }\end{array}$ & $\begin{array}{l}\text { differentiating } \\
\text { - discriminating } \\
\text { - distinguishing } \\
\text { - focusing } \\
\text { - selecting } \\
\text { organizing } \\
\text { - finding coherence } \\
\text { - integrating } \\
\text { - outlining } \\
\text { - parsing } \\
\text { - structuring } \\
\text { attributing } \\
\text { - deconstructing }\end{array}$ & $\begin{array}{l}\text { checking } \\
\text { - coordinating } \\
\text { - detecting } \\
\text { - monitoring } \\
\text { - testing } \\
\text { critiquing } \\
\text { - judging }\end{array}$ & $\begin{array}{l}\text { generating } \\
\text { • hypothesizing } \\
\text { planning } \\
\text { • designing } \\
\text { producing } \\
\text { - constructing }\end{array}$ \\
\hline
\end{tabular}

Figure 2. Increasing complexity of thinking skills (cognitive processes), taken from a handout on the Revised Bloom's Taxonomy by Iowa State University, adapted from Anderson \& Krathwohl (2001: pp. 67-68).

authentic task would be required to provide opportunities for engagement and the development of desired higher-order thinking skills. In developing this task, we seek to incorporate and build upon the research mentioned in this article in an effort to achieve positive student learning outcomes.

At Southern Cross University, Technology Education students (pre-service teachers) who elect to specialise in the Industrial Technology strand of technology teaching undertake a study unit ("subject") called Computer Aided Design and Graphics. This unit is essential for pre-service teachers to develop the required technical drawing and design skills required to teach Graphics Technology as part of the New South Wales suite of elective subjects on offer to school students in Years 9 and 10 (middle high school).

Within the Graphics Technology syllabus, teachers (and possibly their students, but this degree of choice differs from school to school) may choose to offer option modules including Architectural Drawing, Australian Architecture or Computer Aided Design and Drafting (NSWBOS, 2003: p. 14). Due to the registration and teachers accreditation requirements imposed on the Technology Education degree from the New South Wales Institute of Teachers, the expectations are that a pre-service teacher wishing to teach Graphics Technology in New South Wales high schools will have undertaken units of study that incorporate theoretical and practical experiences in Computer Aided Design (CAD) as well as a possible number of optional topics that may include “architecture and architectural drawing” (NSWIT, 2012: p. 8).

Considering the value of past studies by Dewey (1938) and Kolb (1984) in experiential, problem-based learning, the successful educational outcomes of designing distance education learning material to suit student's learning preferences (Gee, 1990; Coggins, 1989; Dunn et al., 1989; Miller et al., 1987), and the positive results in the use of recorded video podcasts (vodcasts) to teach engineering concepts to distance education students asynchronously (Kao, 2008; Rafi et al., 2006), the intention of this article is to determine whether interactive vodcasts can provide students with the procedural knowledge via a distance education pedagogy. To determine this, a drawing assessment task (project base learning) was issued to the Technology Education pre-service teachers enrolled in the unit Computer Aided Graphics and Design. This task required pre-service teachers to design, draw and model a new civic centre (a large multipurpose public building) for a pre-determined site in the New South Wales, mid-north coastal city of Coffs Harbour. The chosen city for the drawing task was insignificant for the purposes of this article, although it is interesting to note that the task was authentic as a new civic centre has been publically debated for a number of years as a much needed facility in the city of Coffs Harbour (Scott, 2014). To develop the pre-service teachers' higher-order thinking skills in analysis, evaluation and creation, the pre-service teachers had to consider the design constraints associated with Local Government planning 
controls, passive solar design principles, and specific functional criteria that would be essential for a functional civic centre.

To complement pre-service teachers' existing knowledge and drawing skills of Trimble (previously owned by Google) SketchUp, a number of instruction videos were previously recorded (vodcasted) using Camtasia, recording the procedures one would undertake in drawing a 3D model using SketchUp software. To cater for a variety of pre-service teachers preferred learning styles, the vodcast-discussing and demonstrating the procedures for drawing sequentially on-screen-incorporated a voice over of these procedures to satisfy the preferred learning styles of what Fleming's VAK model would label as visual and auditory learners (Fleming \& Mills, 1992; Fleming \& Baume, 2006; Leite et al., 2009). These videos were placed in an accessible area of the online content management system called MySCU, and made accessible to all pre-service teachers enrolled in the unit. Noting that some pre-service teachers enrolled in the Technology Education degree live in remote areas and therefore possess varied internet download capabilities, rather than record one video that demonstrated the procedural knowledge from the beginning to the end, bite-sized chunks of video were vodcasted to enable them to be easily accessed in one session (Clifton \& Mann, 2011).

The design and drawing of a large building incorporating specific design constraints can be quite a daunting and complex task for those who have never engaged in any previous work in building design, let alone mastery of a computer-based design and modeling software. The nature of distance education requires pre-service teachers to be disciplined in engaging with the learning material in a self-educative process, and in the case of this task develop a proficient level of competency in using SketchUp. For the purposes of this article, procedural knowledge and skills would be developed by the pre-service teachers asynchronously through the process of watching vodcasts in using SketchUp to draw a building, then practising the drawing techniques themselves to develop their own 3D model building as required in the drawing task.

This method of using vodcasts to supply the procedural knowledge will be the only form of instruction in use of the software, acknowledging that the drawing task will be scaffolding a basic level of procedural knowledge and skills that they have had already gained in a previous unit. To determine whether interactive vodcasts can be used successfully to provide procedural knowledge and skills, the number of pre-service teachers who did not require additional tuition in use of the SketchUp software would be collated and analysed as a percentage of the cohort. The data will be analysed according to the number and level of additional or supplementary assistance required for the pre-service teachers to be able to successfully design and draw a 3D model of a multipurpose building using SketchUp. In terms of the data collected for the number of times students needed procedural knowledge assistance, this can be counted according to the number of questions fielded individually from the pre-service teachers. If a student asks more than one question, this is added to the tally of questions asked. To classify the level of assistance required to supplement the video podcasting pedagogy, if a pre-service teacher asks between one to three questions of the academic, this is classified as minimal supplementary instruction. If, on the other hand, a pre-service teacher asking more than three questions is classified as requiring major supplementary, as they will be experiencing difficulties in relying on the asynchronous use of vodcasting alone to develop their procedural knowledge and skills.

\section{Results}

Fifteen pre-service teachers enrolled in the Computer Aided-Design and Graphics unit. This small number of students is not unusual given that the average annual enrolment in the Technology Education degree is approximately 50 students. As mentioned earlier in the article, the decision to enrol in this unit is based upon the choice of technology strand that the pre-service teacher decides to study. All fifteen of these students are following the Industrial Technology strand of Technology Education.

Following the implementation of the drawing task, no further instruction was given to the cohort. The purpose of this study was to determine whether procedural knowledge and skills could be developed using vodcasts, therefore the data from student feedback relating to procedural skills and knowledge were kept. Interesting feedback that is not essential to this article is that pre-service teachers indicated, after the task, that information such as Local Council planning information and solar design principles was easily obtained online. The Coffs Harbour City council has a detailed section titled "Land Use" on their website (CHCC, 2013). This section is dedicated to land use, planning and development. The planning documentation for any Local Government authority needs to be specific to mitigate any ambiguity for potential developers in an effort to ease investment in 
the city and ensure that all development occurs within the constraints of the planning documentation. Also, while not essential to this article, it is interesting to note that of the fifteen pre-service teachers, three students asked questions relating to the Local Government planning documentation. The three questions were raised from three different the students trying to interpret the language of the planning documentation. The language used in the planning can be quite technical and specific to professionals who work in the planning, and building development industries.

In relation to the purpose of this article and the collation of evaluative data, of the fifteen pre-service teachers engaged in the drawing task, there were three questions from three separate students related to procedural challenges faced when using SketchUp to design and draw their 3D modeled buildings (Table 1; Figure 3).

The three questions dealt with two specific forms of procedural knowledge:

1) Not knowing how to geo-locate their design onto an image of the site. This is a function of the SketchUp software that uses the Geographic Information System (GIS) data from Google Earth. When using this feature, users can choose a site anywhere in a virtual representation of the earth. From a design perspective, this feature is useful as it takes into consideration the path of the sun in determining the passive solar design characteristics of a design that placed (geo-located) in the virtual world.

2) Experiencing difficulty with the push/pull feature to penetrate walls for creating windows or doors (two separate pre-service teachers asked this question). There is a feature in SketchUp that allows the user to push in or pull outward a two-dimensional shape (any geometric shape such as a square, rectangle, circle, etc.) to make it appear three-dimensional. The pulling out of the shape is a simple process, although when the shape is pushed in, it is a subtractive process, meaning that is does not turn the two-dimensional shape into a three-dimensional shape (like the pull feature) but subtracts the volume of the three-dimensional shape. In the context of creating holes in walls for adding windows and doorways, there is a trick to get the accurate subtraction of the three-dimensional shape. It is therefore not surprising that 2 students (13\%) experienced difficulty in performing this specific task.

Table 1. The success of vodcasts in developing procedural knolwedge and skills in using SketchUp: percentage of pre-service teachers requiring additional assistance after engaging with vodcast instruction.

Number of students and the level of supplementary instruction required in using SketchUp (n = 15)

No additional instruction required in using the features of SketchUp (0). Students are able to engage with use video podcasts to learn and develop the procedural knowledge and skills required to successfully design and model a 3D multipurpose building.
Percentage of pre-service teachers $(\%)$

Minimal additional instruction required in using the features of SketchUp (3). Students are mostly able to engage with use video podcasts to learn and develop the procedural knowledge and skills required to successfully design and model a 3D multipurpose building.

20

0

Major additional instruction required in using the features of SketchUp (0). Students are experiencing difficulty in using the video podcasts to learn and develop the procedural knowledge and skills required to successfully design and model a $3 \mathrm{D}$ multipurpose building.

\section{Supplementary instruction}

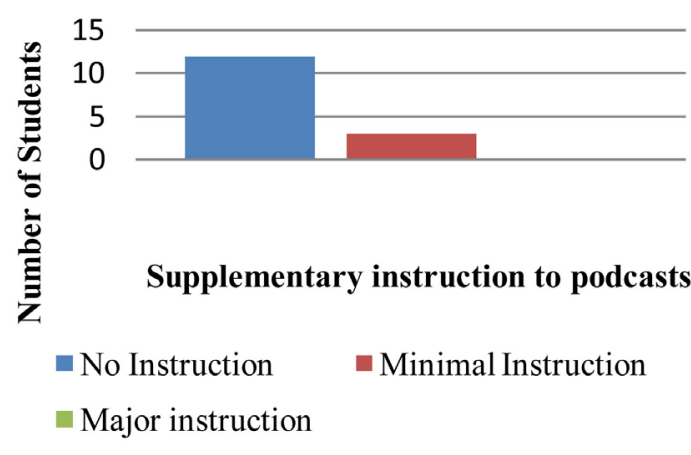

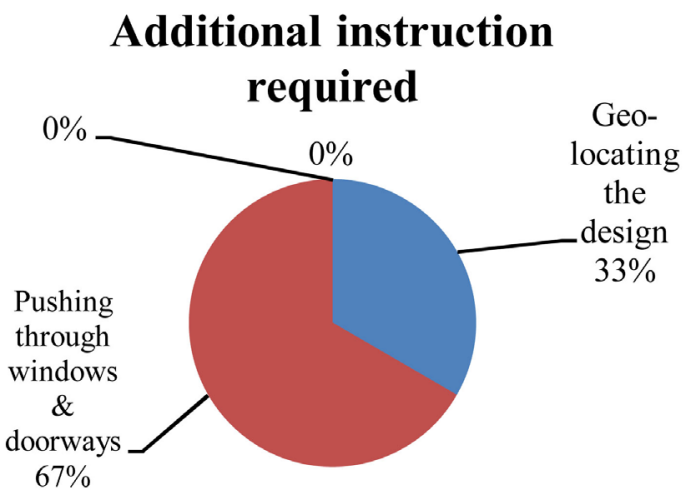

Geo-

cating

thion

$33 \%$

Figure 3. Proportions of supplementary instruction required (left) and nature of additional instruction required (right). 


\section{Discussion}

Student questions regarding Council documentation, and their interpretation, were not considered relevant to this study in determining the effectiveness of interactive videos as a method of developing procedural knowledge and skills via a distance. These questions did not influence the data as they did not relate to the development of procedural knowledge and skills specific to the use of SketchUp in the drawing task. This information was noted, however, as it was interesting to evaluate the student experience in navigating through the Local Government authority's planning and development documentation. In analysing the format of information presented in planning documentation, it is definitely suited to auditory learners. Given that the task was problem-based learning and authentic, it did add to the richness of the student experience. However, the levels of planning documentation and technical jargon may need to be revaluated in subsequent years, ensuring that the task is specific in its focus in developing procedural knowledge and skills in SketchUp, not Local Government planning processes.

In determining the level of success of vodcasting as an effective distance education pedagogy, $80 \%$ of pre-service teachers did not require further instruction, demonstrating that they suitably acquired knowledge and skills presented to them in both visual and kinaesthetic formats. While $80 \%$ is a significant percentage, it is acknowledged that the pre-service teachers have also drawn on procedural knowledge and skills in SketchUp acquired from a previous unit. Though the task given to the students was considerably basic in comparison to the civic centre, one cannot discount the additional self-education that may have resulted from interested students looking to develop their skills further.

Regarding the $20 \%$ of students who required minor tuition, of the short vodcasts developed there was not one that discussed geo-location. The student in question did not struggle with the task as a whole, but found that the geo-location aspects of this task were foreign to them. This relatively small percentage of assistance was surprising given that students were not shown how to do this, although it might support the work of Gee (1990) and Diaz \& Cartnal (1999) that indicate distance education student preferences forthis style of individualised pedagogy, and thus could possibly be considered to be key in success in performing kinaesthetic tasks.

The two pre-service teachers reported having minor difficulty in understanding how to successfully create a window or door every time required the knowledge to perform one specific task (Figure 4). To elaborate fur-

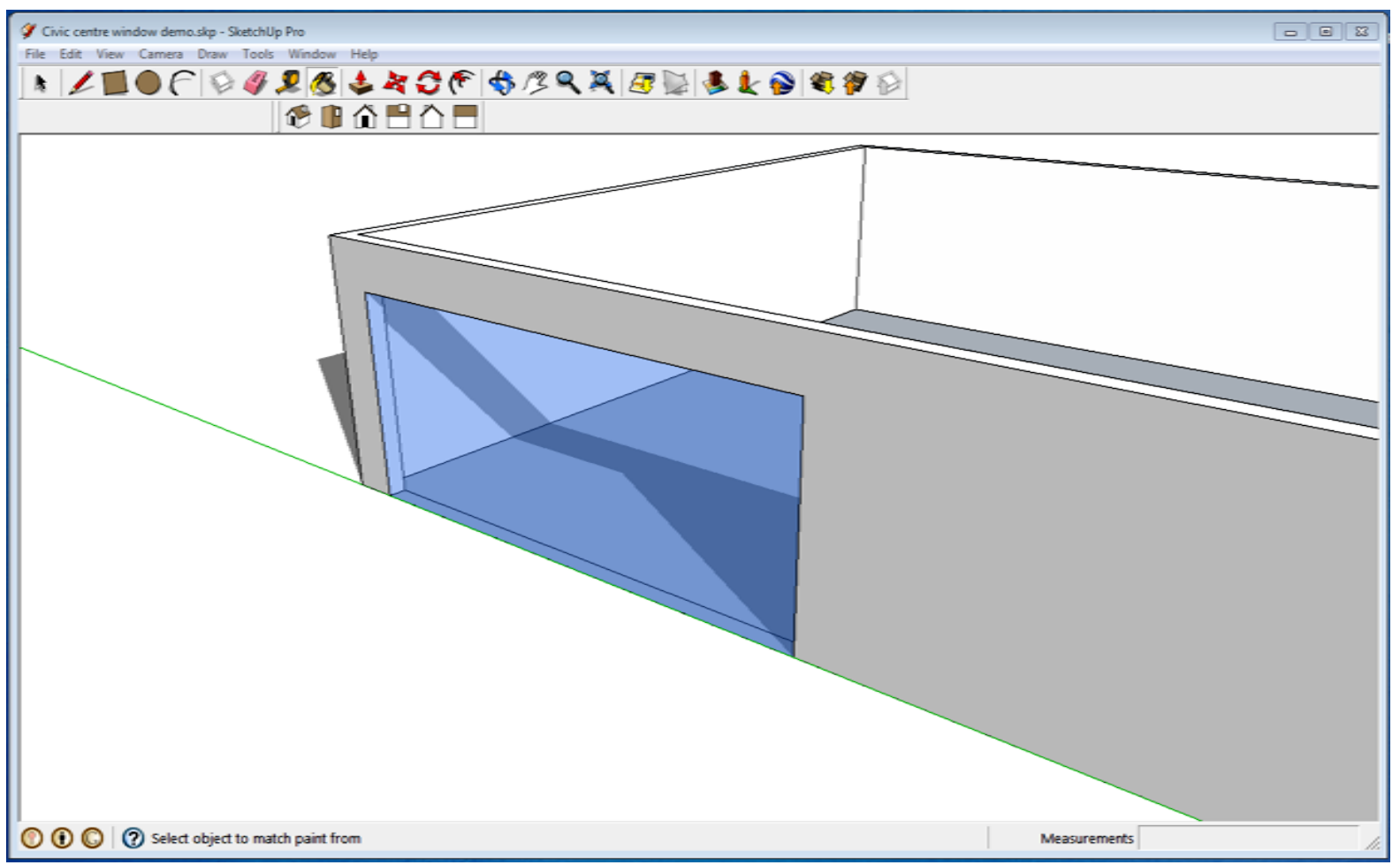

Figure 4. Demonstration of window penetration and making the material translucent. Additional information was required. 
ther, they sought advice on how to ensure that when they penetrated the wall, that the penetration finished exactly at the end of the wall and did not leave any remaining material or extruded additional material. Even though there was a video on creating windows and doors, additional clues were required to present to the students a procedural trick that would ensure their continued success in the future.

In an internal, face-to-face delivery mode, pre-service teachers having preferred learning styles can easily seek instruction from their tutors (or teachers in school settings), tapping into the varied presentation formats that face-to-face delivery offers. However, via a distance, the ability for educators to demonstrate procedures are challenging, and may result in the additional tuition of individual students. In a higher education context, the possibility of tutoring individual students is not an ideal when distance education units may not have the same human resource infrastructure that face-to-face units may have in terms of lecturers and multiple tutors. This problem can compound if the distance education unit has a large cohort of students. As an educator who is fielding new questions, in consideration of how this information may prove useful to other pre-service teachers, the use of phone calls is not an efficient use of time, nor does it cater for the variation in different pre-service teachers' speed and students' preferred learning styles in the understanding of process. Interactive videos have proven to be more effective from this perspective in not only possessing the ability to present to distance education students information in different formats to cater for individual learning preferences, but enable students to engage with the learning material asynchronously. For the pre-service teachers of today, the vodcast learning experience is a tacit knowledge that they can incorporate into their own teaching pedagogy, teaching the digital native using a technology that they are familiar with.

\section{Conclusion}

This article has sought to provide an insight into one style of pedagogy—video podcasting-to develop procedural knowledge and skills to distance education students. As discussed in the work of Kao (2008), Rafi et al. (2006) and Gee (1990), the use technology in developing valid educational tasks must incorporate the characteristics of sound pedagogy to challenge, engage student and interest students to develop a deeper knowledge and understanding. For the experienced educator, they can anticipate the scaffolding required to develop the potential gaps in student knowledge and skills. inexperienced pre-service teachers, however, need to know and recognise good pedagogy before looking to use vodcasting as a teaching tool. Considering this, it is then up to teacher educators in higher education settings to be explicit in the instructional design strategies, to better equip the teachers of the future. den Exter et al. (2012) arrived at equivalent conclusions with regards to the adoption of wikis in teaching and learning. In the meantime, it would be naïve to consider the production of interactive videos would satisfy pre-service teachers' needs entirely, although appropriately managed they can assist both educators and their pre-service teachers in teaching and learning activities in a complementary capacity.

\section{References}

ABS (2010). Education and Training Cat. No. 1301.0 Year Book Australia. Australian Bureau of Statistics. http://www.abs.gov.au/ausstats/abs@.nsf/Lookup/by\%20Subject/1301.0 2012 Main\%20Features Higher\%20education 107

Anderson, J. R., \& Fincham, J. M. (1994). Acquisition of Procedural Skills from Examples. Journal of Experimental Psychology. Learning, Memory \& Cognition, 20, 1322. http://dx.doi.org/10.1037/0278-7393.20.6.1322

Anderson, L. W., \& Krathwohl, D. R. (2001). A Taxonomy for Learning, Teaching and Assessing: A Revision of Bloom's Taxonomy of Educational Objectives: Complete Edition. New York: Longman.

Bloom, B. S. (1968). Learning for Mastery. Instruction and Curriculum. Regional Education Laboratory for the Carolinas and Virginia, Topical Papers and Reprints, Number 1.

Boud, D. (1993). Experience as the Base for Learning. Higher Education Research \& Development, 12, 33-44. http://dx.doi.org/10.1037/0278-7393.20.6.1322

Boyd, W. E., \& Ellis, D. (2013). Sketching up New Geographies: Open Sourcing and Curriculum Development. Australasian Journal of Educational Technology, 29, 403-415.

Boyd, W. E., \& Horta, H. (2011). Network Ethics in the Growing Global, Multi-Dimensional and Technological Academy: Introduction to Articles Presented at the 2009 Network Ethics Conference. International Journal of Cyber Ethics in Education, 1, i-v. http://www.igi-global.com/Files/Ancillary/2155-6903_1_3_Preface.pdf

Boyd, W. E., \& Newton, D. (2011). Times of Change, Times of Turbulence: Seeking an Ethical Framework for Curriculum 
Development during Critical Transition in Higher Education. International Journal of Cyber Ethics in Education, 1, 1-11. http://www.igi-global.com/viewtitlesample.aspx?id=56104 http://dx.doi.org/10.4018/ijcee.2011070101

Brown, R. A., \& Brown, J. W. (2010). What Is Technology Education? A Review of the “Official Curriculum”. Clearing House: A Journal of Educational Strategies, Issues and Ideas, 83, 49-53. http://dx.doi.org/10.1080/00098650903505449

Bourne, J., Harris, D., \& Mayadas, F. (2005). Online Engineering Education: Learning Anywhere, Anytime. Journal of Engineering Education, 94, 131-146. http://dx.doi.org/10.1002/j.2168-9830.2005.tb00834.x

Carroll, J. B. (1963). A Model of School Learning. Teachers College Record, 64, 723-733.

Chi, M. T., \& Ohlsson, S. (2005). Complex Declarative Learning. In Cambridge Handbook of Thinking and Reasoning. Cambridge: Cambridge University Press.

Clifton, A., \& Mann, C. (2011). Can YouTube Enhance Student Nurse Learning? http://www.sciencedirect.com/science/article/pii/S0260691710001802

Coggins, C. C. (1989). Preferred Learning Styles and Their Impact on Completion of External Degree Programs. In M. G. Moore, \& G. C. Clark (Eds.), Readings in Distance Learning and Instruction (No. 2, pp. 1-13). University Park: Pennsylvania State University.

CHCC (2013). Land Use. Coffs Harbour City Council. http://www.coffsharbour.nsw.gov.au/places-for-living/land-use/Pages/land-use.aspx

Cress, U., \& Kimmerle, J. (2008). A Systemic and Cognitive View on Collaborative Knowledge Building with Wikis. International Journal of Computer-Supported Collaborative Learning, 3, 105-122. http://dx.doi.org/10.1007/s11412-007-9035-z

den Exter, K., Rowe, S., Boyd, W., \& Lloyd, D. (2012). Using Web 2.0 Technologies for Collaborative Learning in Distance Education-Case Studies from an Australian University. Future Internet, 4, 216-237. http://dx.doi.org/10.3390/fi4010216

Dewey, J. (1938). Experience and Education. Toronto: Collier-MacMillan.

Diaz, D. P., \& Cartnal, R. B. (1999). Students’ Learning Styles in Two Classes. College Teaching, 47, 130-135. http://dx.doi.org/10.1080/87567559909595802

Drago, W. A., \& Wagner, R. J. (2004). Vark Preferred Learning Styles and Online Education. Management Research News, 27, 1-13. http://dx.doi.org/10.1108/01409170410784211

Dunn, R., Beaudry, J., \& Klavas, A. (1989). Survey of Research on Learning Styles. Educational Leadership, 46, 50-58.

Falchikov, N., \& Boud, D. (1989). Student Self-Assessment in Higher Education: A Meta-Analysis. Review of Educational Research, 59, 395-430. http://dx.doi.org/10.3102/00346543059004395

Feisel, L. D., \& Rosa, A. J. (2005). The Role of the Laboratory in Undergraduate Engineering Education. Journal of Engineering Education, 94, 121-130. http://dx.doi.org/10.1002/j.2168-9830.2005.tb00833.x

Fleming, N., \& Baume, D. (2006). Learning Styles Again: VARKing up the Right Tree! Educational Developments, 7, 4-7. http://www.johnsilverio.com/EDUI6702/Fleming_VARK_learningstyles.pdf

Fleming, N. D., \& Mills, C. (1992). Not Another Inventory, Rather a Catalyst for Reflection. To Improve the Academy, 11, 137.

Gee, D. B. (1990). The Impact of Students' Preferred Learning Style Variables in a Distance Education Course: A Case Study. Unpublished Research/Technical Report, Texas Technical University. http://files.eric.ed.gov/fulltext/ED358836.pdf

Gough, J. E. (1980). The Use of Study Centres in Four Distance Education Systems. Victoria: Deakin University. http://eric.ed.gov/?id=ED220666

Griffiths, M. (2010). Improving the Asynchronous Video Learning Model. PhD Dissertation, Birmingham Young University. http://contentdm.lib.byu.edu/cdm/ref/collection/ETD/id/2074

Hammersley, B. (2004). Audible Revolution. The Guardian. http://www.theguardian.com/media/2004/feb/12/broadcasting.digitalmedia

Healey, M., \& Jenkins, A. (2000). Kolb’s Experiential Learning Theory and Its Application in Geography in Higher Education. Journal of Geography, 99, 185-195. http://dx.doi.org/10.1080/00221340008978967

Henry, J. (1989). Meaning and Practice in Experiential Learning. In S. W. Weil, \& I. McGill (Eds.), Making Sense of Experiential Learning: Diversity in Theory and Practice (pp. 25-37). Milton Keynes: UK Society for Research into Higher Education and Open University Press.

Hymel, G. M. (1988). The Carroll Model of School Learning: A 25-Year Retrospective View of Its Foundational Role in Mastery Learning Theory and Practice. http://eric.ed.gov/?id=ED326555

ITEA (2005). Developing Professionals: Preparing Technology Teachers. Addenda to Technological Literacy Standards Se- 
ries. Advancing Technological Literacy: ITEA Professional Series. International Technology Education Association (ITEA).

Kao, I. (2008). Using Video Podcast to Enhance Students’ Learning Experience in Engineering. American Society for Engineering Education.

https://www.asee.org/documents/sections/middle-atlantic/spring-2008/02-Using-Video-Podcast-to-Enhance-Students-Lear ning-Experience-in-Engineering.pdf

Kolb, D. A. (1984). Experiential Learning: Experience as the Source of Learning and Development. Englewood Cliffs, NJ: Prentice Hall. http://academic.regis.edu/ed205/Kolb.pdf

Leite, W. L., Svinicki, M., \& Shi, Y. Y. (2009). Attempted Validation of the Scores of the VARK: Learning Styles Inventory With Multitrait-Multimethod Confirmatory Factor Analysis Models. Educational and Psychological Measurement, 70, 323-339. http://dx.doi.org/10.1177/0013164409344507

Miller, D., Alway, M., \& McKinley, D. (1987). Effects of Learning Styles and Strategies on Academic Success. Journal of College Student Personnel, 28, 399-404.

NSWBOS (2003). Graphics Technology Years 7-10 Syllabus. New South Wales Board of Studies. http://www.boardofstudies.nsw.edu.au/syllabus_sc/pdf_doc/graphics_tech_710_syl.pdf

NSWIT (2011). Subject Content Requirements for Teaching in a NSW Primary or Secondary School (Abridged). New South Wales Institute of Teachers. http://www.nswteachers.nsw.edu.au/DownloadDocument.ashx?DocumentID=1143

Oosterhof, A. (2012). Types of Changes that Occur as Declarative Knowledge Increases. Tallahassee, FL: Center for Advancement of Learning and Assessment, Florida State University.

http://www.cala.fsu.edu/files/declarative_knowledge.pdf

Parker, A. (2003). Motivation and Incentives for Distance Faculty. Online Journal of Distance Learning Administration, 6. http://www.westga.edu/ distance/ojdla/fall63/parker63.htm

Prensky, M. (2001). Digital Natives, Digital Immigrants. On the Horizon, 9, 1-6. http://dx.doi.org/10.1108/10748120110424816

Putnam, A. R. (1992). What People Mean When They Say They Teach Technology Education. Paper presented at the American Vocational Association Convention, St. Louis, MO, December 1992. http://files.eric.ed.gov/fulltext/ED354335.pdf

Rafi, A., Samsudin, K., \& Ismail, A. (2006). On Improving Spatial Ability through Computer-Mediated Engineering Drawing Instruction. Journal of Educational Technology \& Society, 9, 149-159.

Rudestam, K. E. (2004). Distributed Education and the Role of Online Learning in Training Professional Psychologists. Professional Psychology: Research and Practice, 35, 427-432. http://dx.doi.org/10.1037/0735-7028.35.4.427

Schwan, S., \& Riempp, R. (2004). The Cognitive Benefits of Interactive Videos: Learning to Tie Nautical Knots. Learning and Instruction, 14, 293-305. http://www.sciencedirect.com/science/article/pii/S0959475204000337 http://dx.doi.org/10.1016/j.learninstruc.2004.06.005

Scott, B. (2014). Coffs Harbour Entertains the Idea of a Major Project. http://www.coffscoastadvocate.com.au/news/entertaining-an-idea/2227332/

Shin, D. H. (2009). The Evaluation of User Experience of the Virtual World in Relation to Extrinsic and Intrinsic Motivation, International Journal of Human-Computer Interaction, 25, 530-553. http://dx.doi.org/10.1080/10447310902963951

Shin, D. H., \& Kim, W. Y. (2008). Applying the Technology Acceptance Model and Flow Theory to Cyworld User Behavior: Implication of the Web 2.0 User Acceptance. CyberPsychology \& Behavior, 11, 378-382.

http://dx.doi.org/10.1089/cpb.2007.0117

Thompson, C., \& Absalom, M. (2011). Working with Wikis: Collaboration, Authorship and Assessment in Higher Education. In S. M. Barton, J. Hedberg, \& K. Susuki (Eds.), Global Learn Asia Pacific 2011 (pp. 375-384). Melbourne: AACE.

van Aalst, J. (2009). Distinguishing Knowledge-Sharing, Knowledge-Construction, and Knowledge-Creation Discourses. International Journal of Computer-Supported Collaborative Learning, 4, 259-287. http://dx.doi.org/10.1007/s11412-009-9069-5

Williams, P. P. (2009). Technological Literacy: A Multliteracies Approach for Democracy. International Journal of Technology \& Design Education, 19, 237-254. http://dx.doi.org/10.1007/s10798-007-9046-0 
Scientific Research Publishing (SCIRP) is one of the largest Open Access journal publishers. It is currently publishing more than 200 open access, online, peer-reviewed journals covering a wide range of academic disciplines. SCIRP serves the worldwide academic communities and contributes to the progress and application of science with its publication.

Other selected journals from SCIRP are listed as below. Submit your manuscript to us via either submit@scirp.org or Online Submission Portal.
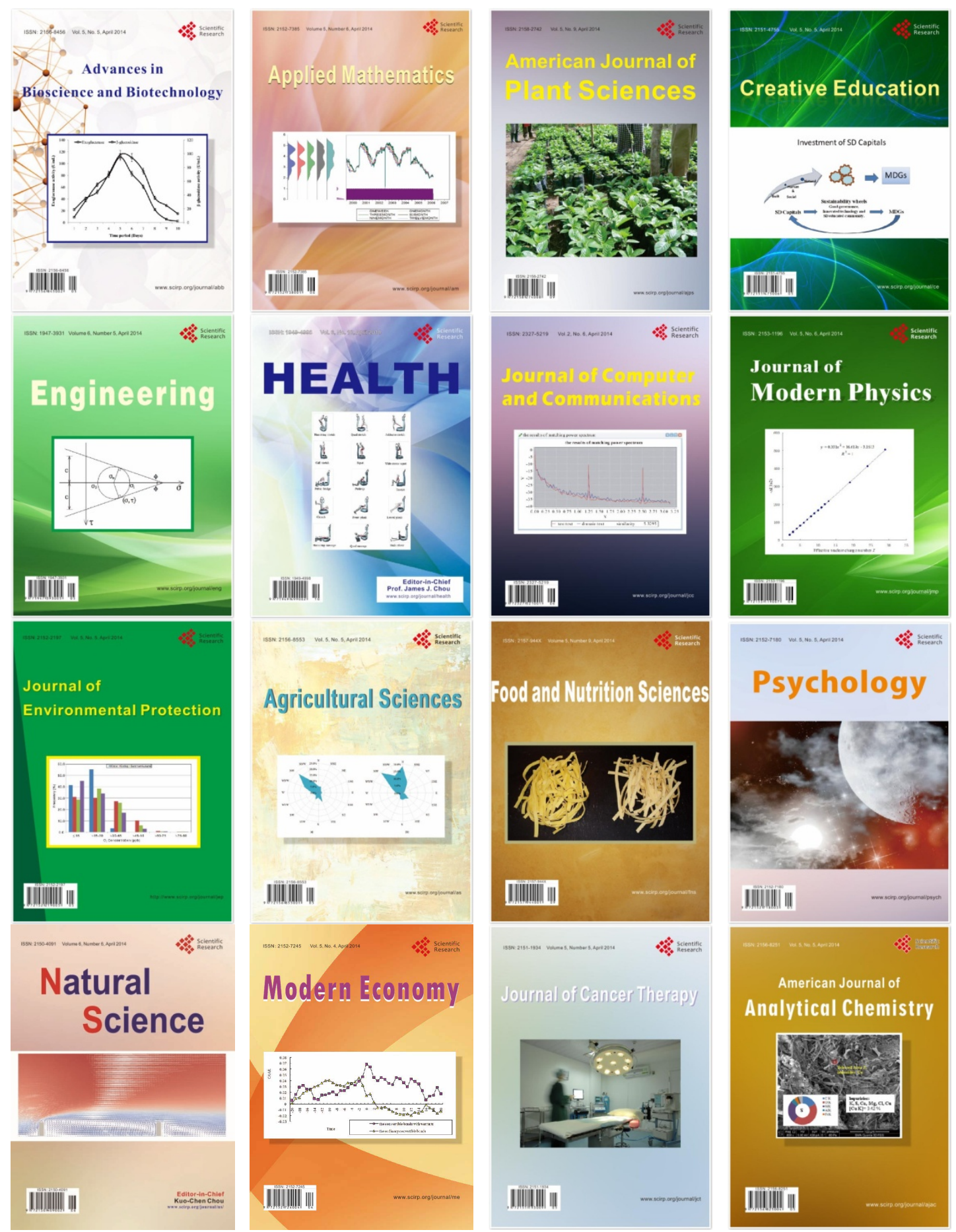